\title{
Interleukins IL-6, IL-8, IL-10, IL-12 and periimplant disease. An update
}

\author{
Maria-Eugenia Candel-Martí ${ }^{1}$, Antonio-Juan Flichy-Fernández ${ }^{2}$, Teresa Alegre-Domingo ${ }^{2}$, Javier Ata-Ali ${ }^{3}$, \\ Maria A. Peñarrocha-Diago ${ }^{4}$
}

\begin{abstract}
${ }^{1}$ DDS. Resident of the Master in Oral Surgery and Implantology. Valencia University Medical and Dental School
${ }^{2}$ DDS. Master in Oral Surgery and Implantology. Collaborating Professor of the Master in Oral Surgery and Implantology. Valencia University Medical and Dental School

${ }^{3}$ DDS. Master in Oral Medicine and Surgery. Resident of the Master in Oral Surgery and Implantology. Valencia University Medical and Dental School

${ }^{4}$ Assistant Professor in Oral Surgery and Implantology. Valencia University Medical and Dental School. Spain
\end{abstract}

Correspondence:

Cirugía Bucal,

Clínicas Odontológicas,

Gascó Oliag 1,

46021 Valencia (Spain)

Maria.Penarrocha@uv.es

Received: 18/02/2010

Accepted: 26/08/2010

Candel-Martí ME, Flichy-Fernández AJ, Alegre-Domingo T, Ata-Ali J, Peñarrocha-Diago MA. Interleukins IL-6, IL-8, IL-10, IL-12 and periimplant disease. An update. Med Oral Patol Oral Cir Bucal. 2011 Jul 1;16 (4):e518-21.

http://www.medicinaoral.com/medoralfree01/v16i4/medoralv16i4p518.pdf

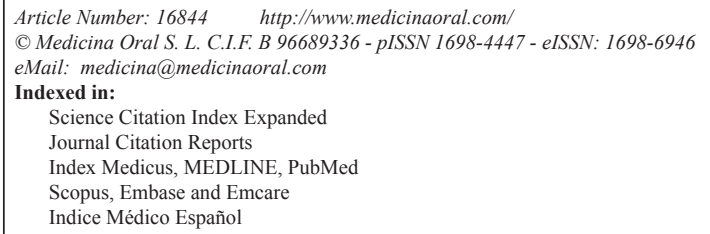

\begin{abstract}
Introduction: A study is made of the usefulness of cytokines (such as interleukin-6 (IL-6), interleukin-8 (IL-8), interleukin-10 (IL-10) and interleukin-12 (IL-12)) as markers of periimplant disease (mucositis and periimplantitis). An increase in the levels of these cytokines in dental implant crevicular fluid may give rise to a lack of osteointegration, bone loss or implant failure.

Objective: To review the literature relating IL-6, IL-8, IL-10 and IL-12 levels to dental implant surgery and periimplantitis.

Material and Method: A PubMed literature search was made of articles in English and Spanish, using the key words "cytokine and dental implants", cytokine and periimplantitis", "IL-6, IL-8, IL-10, IL-12 and dental implants", "IL-6, IL-8, IL-10, IL-12 and periimplantitis". Fourteen articles were found and classified into two groups relating interleukin levels to: a) periimplant disease; and b) their influence upon dental implant osteointegration without periimplant disease.

Conclusions: An increase in interleukin levels is observed in patients with periimplant disease, though there is controversy over the effect of interleukins in crevicular fluid and periimplantitis in relation to implant failure or the development of periimplant disease.
\end{abstract}

Key words: Cytokines, interleukins, periimplantitis, IL-6, IL-8, IL-10, IL-12, dental implants. 


\section{Introduction}

The usefulness of cytokines (such as interleukin-6 (IL-6), interleukin-8 (IL-8), interleukin-10 (IL-10) and interleukin-12 (IL-12)) as markers of periimplant disease (mucositis and periimplantitis) has been investigated (1). The cytokines are multifunctional proteins and glycoproteins that act as intercellular regulatory factors at both local and systemic level. They are produced by immunocompetent cells such as $\mathrm{T}$ lymphocytes and monocytes in local inflammatory tissue infiltrates. Periodontal tissue components such as fibroblasts and epithelial and endothelial cells also participate in cytokine formation during inflammatory responses (2).

Periodontal health depends on the local balance among reactive and suppressor immune cells, their cytokines and mediators. Cytokines IL-6, IL- 8 and IL-12 have proinflammatory functions, and induce bone reabsorption $(1,3)$, while IL-10 exerts antiinflammatory effects (3). In the oral cavity it has been seen that the plasma cytokine levels increase after surgery (2). In this context, dental implant surgery releases a large amount of cytokines at local level as a body response to surgical aggression, and these levels gradually decrease over the subsequent 8 months $(3,4)$. Cytokine release after this period of time is regarded as an important factor in the development of periimplant disease.

The present study involves a literature review of the studies relating IL-6, IL-8, IL-10 and IL-12 levels to dental implant treatment, evaluating their implication in periimplant inflammation and their influence upon osteointegration, with a view to establishing whether increased cytokine concentrations in the periimplant sulcus (crevicular fluid) are correlated to an early diagnosis of periimplant disease.

\section{Material and Method}

A PubMed literature search was made of articles in English and Spanish, using the key words "cytokine and dental implants", cytokine and periimplantitis", "IL-6, IL-8, IL-10, IL-12 and dental implants", "IL-6, IL-8, IL10, IL-12 and periimplantitis". Fourteen articles relating the levels of the abovementioned cytokines to dental implant treatment and periimplantitis were found (12 in vivo studies and two in vitro studies) - an evaluation being made of interleukin influence upon periimplant disease and the osteointegration period of dental implants in the absence of periimplant disease.

\section{Results and Discussion}

Influence of interleukins 6, 8, 10 and 12 upon periimplant inflammation

The increase in cytokine concentration in the crevicular fluid of dental implants may lead to a lack of osteointegration, bone loss or implant failure (5-7). Bone is a dynamic tissue continuously subject to remodeling through reabsorption and formation, these processes being controlled by the local production of cytokines, among other factors (4).

Some of the studies in our review reported increased levels of IL-6, IL-8, IL-10 and IL-12 in periimplant disease, revealing their implication in the destruction of periimplant tissue and their usefulness as markers of periimplant disease $(1,2,4,7-9)$. In contrast, other authors observed no relationship between IL-6 and IL10 levels and periimplant disease $(2,7,8,10)$, discarding their implication in early dental implant loss (4).

Regarding IL-6, Liskmann et al. (1), on studying the levels of IL- 6 in the crevicular fluid of the periimplant sulcus in 30 patients, recorded increased concentrations in patients with periimplant disease - a positive correlation being observed with the clinical parameters (bleeding, pocket depth and gingival index). These authors examined the usefulness of cytokine concentration as a marker of periimplant disease, and in evaluating the capacity of the patient immune system to maintain an inflammatory balance. Konttinen et al. (9) recorded higher IL-6 levels in patients with periimplantitis than in healthy subjects - the difference being statistically significant. These authors concluded that periimplant disease is amenable to treatment with cytokine modulators. In contrast, Mengel et al. (10), on comparing the IL-6 and IL-1 $\beta$ levels in 5 partially edentulous patients with severe periodontitis of the remaining teeth and subjected to dental implant rehabilitation versus patients without periodontal disease, reported higher levels in dental implant patients with periodontitis - the difference failing to reach statistical significance. Salcetti et al. (7) likewise recorded no differences in the levels of IL-6 on comparing patients with failed implants versus those with stable dental implants. Campos et al. (5), in 74 patients, analyzed the relationship between the polymorphic gene encoding for IL-6 and early dental implant loss. They concluded that such polymorphism does not constitute a genetic risk factor for early implant loss.

Nowzari et al. (6) in turn studied cytokine and bacterial levels between teeth and dental implants in healthy subjects. An increased cytokine presence was noted in patients with dental implants (two-fold in the case of IL-8). This increase in cytokines was greater in the presence of a larger number of periodontal disease-inducing bacteria. The authors concluded that although these were healthy individuals, there is an inevitable and continuous change in microorganisms and interleukins around teeth and implants.

As regards IL-10, Liskmann et al. (1) reported a higher concentration of IL-10 in patients with periimplantitis. In contrast, Duarte et al. (8) observed no differences between healthy subjects and patients with disease. In another study, Duarte et al. (11) evaluated the efficacy of 
mechanical treatment for mucositis and periimplantitis. An improvement in the clinical parameters was noted, together with improvement in the levels of TNF- $\alpha$ and the OPG/RANKL ratio three months after such treatment, without differences in the levels of IL -10 and IL12.

On correlating IL-12 concentrations in 48 patients to plaque accumulation, pocket depth, bleeding (spontaneous or in response to probing) and suppuration, Duarte et al. (8) concluded that these concentrations are higher in advanced periimplantitis, with increased plaque accumulation, bleeding and pocket depth. They identified IL-12 as a critical factor in destruction of the periodontium.

In an in vitro study, Bordin et al. (12) evaluated the fibroblasts of patients with periimplantitis, patients with periodontitis, and healthy subjects. They found that the fibroblasts of the patients with periimplantitis and periodontitis synthesized more IL- 6 and IL-8, and thus presented a more accentuated proinflammatory profile (Table 1).
On examining the composition of dental implants, Spyrou et al. (13) found that all titanium alloys of different compositions and roughness generated the same amount of interleukins.

Influence of interleukins upon the osteointegration period of dental implants without periimplant disease

Variations are observed in the levels of cytokines in crevicular fluid from the time of dental implant surgery to one year after fitting of the prosthesis, without the obligate presence of periimplant disease.

Twenty-four hours after placement of the dental implants, Pietruski et al. (14) observed a significant increase in IL-6 and IL-8 levels, thus reflecting the presence of local inflammation on the day after surgery, inherent to the surgical trauma, and forming part of the body regeneration and repair response. These levels in turn decreased four months after surgery. Khoury et al. (15), on exploring the influence of antibiotic prophylaxis prior to implant surgery, reported improvement in the clinical parameters one week after surgery, without modifications in cytokine levels (Table 2).

Table 1. Variations in the concentrations of different cytokines according to the literature.

\begin{tabular}{|c|c|c|c|c|}
\hline & IL-6 & IL- 8 & IL- 10 & IL -12 \\
\hline $\begin{array}{l}\text { Liskmann et al. } \\
2006 \text { (1) }\end{array}$ & $\begin{array}{l}\text { Increase in periimplantitis } \\
\qquad(p<0.05)\end{array}$ & $\begin{array}{l}\text { Increase in } \\
\text { periimplantitis }\end{array}$ & & \\
\hline $\begin{array}{l}\text { Konttinen et al. } \\
2006(9)\end{array}$ & $\begin{array}{l}\text { Increase in periimplantitis } \\
\qquad(\mathrm{p}<0.05)\end{array}$ & & & \\
\hline $\begin{array}{l}\text { Mengel et al. } \\
1996(10)\end{array}$ & $\begin{array}{l}\text { Increase in periimplantitis } \\
\qquad(p>0.05)\end{array}$ & & & \\
\hline $\begin{array}{l}\text { Salcetti et al. } \\
1997(7)\end{array}$ & $\begin{array}{l}\text { Increase in healthy subjects } \\
\quad=\text { periimplantitis }\end{array}$ & & & \\
\hline $\begin{array}{c}\text { Duarte et al. } \\
2009(8)\end{array}$ & & $\begin{array}{l}\text { Healthy subjects } \\
=\text { periimplantitis }\end{array}$ & $\begin{array}{l}\text { Increase in } \\
\text { periimplantitis }\end{array}$ & \\
\hline $\begin{array}{l}\text { Duarte et al. } \\
2009(11)\end{array}$ & & $\begin{array}{c}\text { Same after } \\
\text { treatment }\end{array}$ & $\begin{array}{c}\text { Same after } \\
\text { treatment }\end{array}$ & \\
\hline $\begin{array}{l}\text { Bordin et al. } \\
2009(12)\end{array}$ & $\begin{array}{l}\text { Increase in periimplantitis } \\
\qquad(\mathrm{p}<0.05)\end{array}$ & & & $\begin{array}{l}\text { Increase in } \\
\text { periimplantitis }\end{array}$ \\
\hline
\end{tabular}

Table 2. Variations in the concentrations of different cytokines according to time.

\begin{tabular}{|l|l|c|c|}
\hline & 24 h postsurgery & $\begin{array}{c}\text { 4 months with } \\
\text { prosthesis }\end{array}$ & $\begin{array}{c}\text { 8 months with } \\
\text { prosthesis }\end{array}$ \\
\hline $\begin{array}{l}\text { Pietruski et al. } \\
2001 \text { (14) }\end{array}$ & Increase in IL-6, IL-8 & & \\
\hline $\begin{array}{l}\text { Schierano et al. } \\
2003 \text { (3) }\end{array}$ & & $\begin{array}{c}\text { - Increase in IL-10 } \\
\text { - IL-12 only in } \\
\text { chronic inflammation }\end{array}$ & $\begin{array}{c}\text { Decrease in IL-6, } \\
\text { IL-8, IL-10 }\end{array}$ \\
\hline $\begin{array}{l}\text { Schierano et al. } \\
2000(4)\end{array}$ & & & $\begin{array}{c}\text { Decrease in IL-6, } \\
\text { IL-8, IL-10 }\end{array}$ \\
\hline
\end{tabular}


Four months after prosthesis placement, Schierano et al. (3) recorded a considerable increase in the levels of IL-10, reflecting the role of the latter in the regulation of periimplant mucosal inflammation. The authors concluded that a short-term inflammatory response took place in the periodontium. Regarding IL-12, this cytokine was only detected after four months in one patient with chronic inflammation (Table 2).

Eight months after prosthesis placement, Schierano et al. $(3,4)$ recorded a decrease in IL-6, IL-8 and IL-10, reflecting the influence of these cytokines in osteointegration and in lessened bone reabsorption secondary to dental loss (Table 2).

\section{Observations of the authors}

Factors influencing cytokine levels:

Periimplant disease:

- An increase in IL-6, IL-10 and IL-12 in periimplant disease has been demonstrated in three studies $(1,9,11)$, while four articles $(5,7,10,11)$ have reported no relationship between periimplant disease and early implant loss and interleukin concentration.

Treatment:

- The interleukin levels in patients with periimplant disease do not improve after mechanical treatment (11).

Time:

- In patients without periimplant disease, the proinflammatory cytokines $(7,8)$ decrease four months after surgery according to Pietruski et al. (14), and 8 months after prosthesis placement according to Schierano et al. $(3,4)$. IL-12 does not appear under conditions of periimplant health, and disappears entirely 12 months after fitting the prosthesis.

Surgery versus maintenance:

- It is important not to confuse the rise in cytokines observed as a result of surgical trauma (secreted by the body as part of the regeneration and repair response to injury) with the increase seen in inflammation caused by the bacterial biofilm in general, and by periodontal disease-inducing bacteria in the context of pre-established periimplantitis.

An increase in interleukins is observed in patients with periimplant disease, though controversy exists over the effect of the interleukins in crevicular fluid and periimplantitis, regarding their correlation to implant failure or the development of periimplant disease.

\section{References}

References with links to Crossref-DOI

1. Liskmann S, Vihalemm T, Salum O, Zilmer K, Fischer K, Zilmer M. Correlations between clinical parameters and interleukin- 6 and interleukin-10 levels in saliva from totally edentulous patients with peri-implant disease. Int J Oral Maxillofac Implants. 2006;21:54350 .

2. López Carriches C, Martínez González JM, Donado Rodríguez M. Variations of interleukin-6 after surgical removal of lower third molars. Med Oral Patol Oral Cir Bucal. 2006;11:E520-6.

3. Schierano G, Bellone G, Cassarino E, Pagano M, Preti G, Emanuelli G. Transforming growth factor-beta and interleukin 10 in oral implant sites in humans. J Dent Res. 2003;82:428-32.

4. Schierano G, Bassi F, Gassino G, Mareschi K, Bellone G, Preti G. Cytokine production and bone remodeling in patients wearing overdentures on oral implants. J Dent Res. 2000;79:1675-82.

5. Campos MI, Godoy dos Santos MC, Trevilatto PC, Scarel-Caminaga RM, Bezerra FJ, Line SR. Interleukin-2 and interleukin-6 gene promoter polymorphisms, and early

failure of dental implants. Implant Dent. 2005;14:391-6.

6. Nowzari H, Botero JE, DeGiacomo M, Villacres MC, Rich SK. Microbiology and cytokine levels around healthy dental implants and teeth. Clin Implant Dent Relat Res. 2008;10:166-73.

7. Salcetti JM, Moriarty JD, Cooper LF, Smith FW, Collins JG, Socransky SS, et al. The clinical, microbial, and host response characteristics of the failing implant. Int J Oral Maxillofac Implants. 1997;12:32-42.

8. Duarte PM, De Mendonça AC, Máximo MB, Santos VR, Bastos MF, Nociti Júnior FH. Differential cytokine expressions affect the severity of peri-implant disease. Clin Oral Implants Res. 2009;20:514-20.

9. Konttinen YT, Lappalainen R, Laine P, Kitti U, Santavirta S, Teronen O. Immunohistochemical evaluation of inflammatory mediators in failing implants. Int J Periodontics Restorative Dent. 2006;26:13541

10. Mengel R, Stelzel M, Hasse C, Flores-de-Jacoby L. Osseointegrated implants in patients treated for generalized severe adult periodontitis. An interim report. J Periodontol. 1996;67:782-7.

11. Duarte PM, De Mendonça AC, Máximo MB, Santos VR, Bastos MF, Nociti FH. Effect of anti-infective mechanical therapy on clinical parameters and cytokine levels

in human peri-implant diseases. J Periodontol. 2009;80:234-43.

12. Bordin S, Flemmig TF, Verardi S. Role of fibroblast populations in peri-implantitis. Int J Oral Maxillofac Implants. 2009;24:197-204. 13. Spyrou P, Papaioannou S, Hampson G, Brady K, Palmer RM, McDonald F. Cytokine release by osteoblast-like cells cultured on implant discs of varying alloy compositions. Clin Oral Implants Res. 2002;13:623-30

14. Pietruski JK, Pietruska MD, Stokowska W, Pattarelli GM. Serum levels of interleukin-1 (IL-1), interleukin-6 (IL-6) and interleukin-8 (IL-8) in patients treated with dental implants. Rocz Akad Med Bialymst. 2001;46:28-37.

15. Khoury SB, Thomas L, Walters JD, Sheridan JF, Leblebicioglu B. Early wound healing following one-stage dental implant placement with and without antibiotic prophylaxis: a pilot study. J Periodontol. 2008:79:1904-12. 